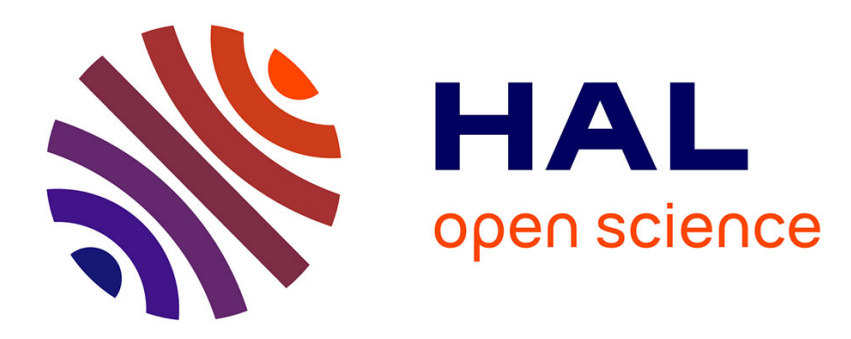

\title{
Mating system and multiple paternity in Hedysarum coronarium L. (Fabaceae)
}

Imene Louati-Namouchi, Mehdi Louati, Ali Chriki

\section{To cite this version:}

Imene Louati-Namouchi, Mehdi Louati, Ali Chriki. Mating system and multiple paternity in Hedysarum coronarium L. (Fabaceae). Agronomie, 2000, 20 (6), pp.655-663. 10.1051/agro:2000157 . hal-00886068

\section{HAL Id: hal-00886068 https://hal.science/hal-00886068}

Submitted on 1 Jan 2000

HAL is a multi-disciplinary open access archive for the deposit and dissemination of scientific research documents, whether they are published or not. The documents may come from teaching and research institutions in France or abroad, or from public or private research centers.
L'archive ouverte pluridisciplinaire HAL, est destinée au dépôt et à la diffusion de documents scientifiques de niveau recherche, publiés ou non, émanant des établissements d'enseignement et de recherche français ou étrangers, des laboratoires publics ou privés. 


\title{
Original article
}

\section{Mating system and multiple paternity in Hedysarum coronarium L. (Fabaceae)}

\author{
Imene Louati-NAmouchi*, Mehdi Louati, Ali Chriki \\ Laboratoire de Génétique, Faculté des Sciences de Bizerte, 7021 Zarzouna, Tunisia
}

(Received 14 January 2000, accepted 3 April 2000)

\begin{abstract}
The mating system was studied in four populations of Hedysarum coronarium under the mixed-mating model (MMM) and the effective selfing model (ESM) by analysis of progeny arrays. Multilocus population outcrossing rates ranged from 0.822 to 1.013 . Pollination experiments indicated that $H$. coronarium is self-compatible, and therefore the high outcrossing rates were attributed to inbreeding depression. This view was supported by high levels of seed abortion in self pollination when compared to open pollination. The effective selfing rate ranged from $\mathrm{E}=0.026$ to $\mathrm{E}=$ 0.183. Positive covariance of selfing with gene fixation $(\mathrm{D}=0.085)$ was observed in one population and could be attributed to subpopulation structure and mating between relatives.

Estimates of the level of multiple paternity under the correlated mating model (CMM) was assessed at the progeny array level. The correlation of the outcrossed paternity $\left(\mathrm{r}_{\mathrm{p}}\right)$ ranged from 0.029 to 0.342 and according to the outcrossing rates, up to $80 \%$ of the total seeds in a progeny array may have different male parents.
\end{abstract}

Hedysarum coronarium / outcrossing rate / progeny array / effective selfing / multiple paternity

Résumé - Régime de reproduction et paternité multiple chez Hedysarum coronarium L. (Fabaceae). L'étude du régime de reproduction a été réalisée chez quatre populations de Hedysarum coronarium en utilisant le modèle de reproduction mixte et le modèle d'autofécondation par l'analyse des tableaux de descendances. Les taux d'allogamie multilocus des populations varient de 0,822 à 1,013 . Des expériences de pollinisation ont montré que $H$. coronarium est autocompatible et les taux d'allogamie élevés peuvent être attribués à la dépression de consanguinité. Ce point de vue est soutenu par l'augmentation du taux d'avortement des graines en autopollinisation manuelle.

Le taux d'autofécondation $(E)$ varie de 0,026 à 0,183 . Une covariance positive $(D=0.085)$ entre $E$ et l'indice de fixation des parents a été observée chez une des quatre populations. Elle peut être attribuée à la présence de subdivision au sein de cette population et à des croisements entre apparentés.

Le taux de paternité multiple a été évalué sous le modèle de reproduction corrélée. La corrélation de paternité chez les descendants issus d'allocroisement $\left(r_{p}\right)$ varie de 0,029 à 0,342 . En se basant sur les taux d'allogamie obtenus, la proportion des graines issues d'une plante mère et ayant des parents mâles différents peut s'élever à $80 \%$.

Hedysarum coronarium / autofécondation / paternité multiple / tableau de descendants / taux d'allogamie

Communicated by Mervyn Humphreys (Aberystwyth, UK)

* Correspondence and reprints

m.louati@excite.com 


\section{Introduction}

Mating systems have a profound influence on the extent and structure of genetic variation in plant populations. Outbreeding populations are expected to have greater genetic diversity, higher levels of heterozygosity and less differentiation among populations than self-fertilized populations $[5,9]$. Plants exhibit a variety of mating systems which include self-fertilization, outcrossing, or a mixture of both. The consequences of these different mating systems will markedly affect the structure and the evolution of populations [9].

The mixed mating model $[4,18,33]$ gives a robust procedure for estimating mating system parameters. However, other approaches have been developed permitting further investigations of demographic and genetic causes of mating patterns. The effective selfing model $[25,26]$ calculates mating system parameters in spatially structured populations by considering mating among relatives and selfing in the estimate of effective selfing.

In multiseeded fruit, outcrossed progeny may share the same male parent if siring pollen derives from one source [35] or one pollination event [23]. Correlation of outcrossed paternal parentage has been reported for several species [15, 22, 23].

The genus Hedysarum (Fabaceae) contains a number of species distinguishable by their different morphology, reproductive systems, karyotype features and geographical origins [1]. In Tunisia, the Dorsal mountains separate the semi-temperate ecological domain of $H$. coronarium and $H$. capitatum to the north and the arid ecological domain of $H$. carnosum and $\mathrm{H}$. eu-spinosissimum to the south [2].

Hedysarum coronarium is distributed in the western mediterranean basin where it grows wild. It is grown for fodder in a number of countries including Spain, Italy and North Africa. In Tunisia, the species has been studied by numerous authors and exhibits considerable variability $[11,17,39$, 40] and a predominantly allogamous mating system $[7,14]$.
In this study, mating system parameters of $H$. coronarium were estimated. The information obtained should help to explain the distribution of genetic diversity in this species.

\section{Materials and methods}

Hedysarum coronarium is an entomophilous species, and bees (Apis mellifera $\mathrm{L}$.) visit the flowers. Both self-and cross-fertilization may occur and both depend fully on insects. A plant can self-fertilize after mechanical stimulation of the stigma by visiting insects, so-called "tripping".

A pollination program was conducted in the greenhouse of the Faculté des Sciences de Bizerte (Tunisia) to determine the levels of self-compatibility of $H$. coronarium. Thirty plants per population, raised from seeds (collected from wild populations), were grown to flowering and a mean of fourteen plants from each population were allocated to hand self-pollination and open-pollination. Percentage of pod set, mean seed numbers per pod and mean number of aborted seeds per pod were calculated for each of the two pollination treatments.

The populations used in the study of the mating system are listed in Table I. At each sampling site, seeds were harvested in early June. From each adult, several multipoded infrutescences (up to ten) were collected. Seeds from the same maternal parent were bulked. Twenty seeds per maternal parent were germinated and only eight were used in electrophoresis. From each seedling, the coleoptile was crushed with a glass rod in $50 \mu \mathrm{l}$ of extraction buffer [41]. Extraction was performed directly in Eppendorf tubes over an ice bath. Extracts were absorbed onto $3 \times 10 \mathrm{~mm}$ whatman paper wicks, and inserted into a $13 \%(\mathrm{w} / \mathrm{v})$ starch gel for horizontal electrophoresis. The buffer used was Histidine pH 6.2 [41]. The enzyme systems studied were: isocitric dehydrogenase (IDH), shikimic dehydrogenase (SKDH), 6-phosphogluconate dehydrogenase (6-PGD), phosphogluco-isomerase (PGI), Malate dehydrogenase (MDH) and phosphoglucomutase (PGM). Only two loci were 
Table I. Populations and progeny array characteristics.

\begin{tabular}{lccccc}
\hline Population & Number of families & Total progeny size & Density & Morph & Flowers \\
\hline El Alia & 24 & 192 & Low & Prostrate & Red violet corolla \\
Maktar & 28 & 224 & Medium & Prostrate & Violet corolla \\
Tunis & 24 & 192 & Medium & Prostrate & Red violet corolla \\
Amaïria & 25 & 200 & High & Erect & Red violet corolla \\
\hline
\end{tabular}

polymorphic enough to be used in mating system analysis: Pgi-2 and Skdh-1.

We used the computer program MLTR version 1.1 [30] to estimate multilocus $\mathrm{t}_{\mathrm{m}}$ and average single-locus outcrossing rates $t_{\mathrm{s}}$ at population level under the mixed-mating model (MMM). Standard errors of $t_{m}, t_{s}$ and their difference $t_{m}-t_{s}$ were calculated using 300 bootstrap replicates.

In contrast to the mixed mating model, the effective selfing model (ESM) assumes equality of gene frequencies among pollen and ovules. At least 24 maternal parents are needed to obtain reliable estimates. The program ESR developed by Ritland [29] estimates the total amount of "apparent selfing", also termed "effective selfing", at a single locus caused by either self-fertilization or mating to relatives. Joint maximum likelihood estimates of gene frequency, the inbreeding coefficient of parents $(\mathrm{F})$, the selfing rate of inbred $\left(\mathrm{S}_{\mathrm{i}}\right)$ and outbred parents $\left(\mathrm{S}_{\mathrm{o}}\right)$ were calculated $[26,32]$. Three further estimates were subsequently obtained based on ESM [31, 32]. Firstly, the effective selfing rate $\mathrm{E}=$ $\mathrm{F} \mathrm{S}_{\mathrm{i}}+(1-\mathrm{F}) \mathrm{S}_{\mathrm{o}}$ which equals the self-fertilization rate when there are no consanguineous matings, although population substructure may cause it to be greater than the self-fertilization rate [31]. Secondly, the inbreeding assortative selfing rate (D), also called the covariance of effective selfing with parental gene fixation, $\mathrm{D}=\mathrm{F}(1-\mathrm{F})\left(\mathrm{S}_{\mathrm{i}}-\mathrm{S}_{\mathrm{o}}\right)$. Positive $D$ maintains the variation of $F$ among neighbourhoods and is an indicator of nonself inbreeding. The third parameter is the change in the fixation index from parents to progeny $(\Delta \mathrm{F})$. Changes in F-values between generations will give an indication of whether any selection against homozygotes or heteterozygotes occurs during later stages of the life cycle.
Correlated mating is another facet of the mating system, and the correlated mating model (CMM) is a parametric approach to mating system estimation that accounts for covariances among mating events $[27,28]$. Two parameters of correlated matings were estimated with the program MLTR: the correlation of outcrossing rate within progeny arrays $\left(\mathrm{r}_{\mathrm{t}}\right)$ and the correlation of outcrossed paternity within progeny arrays $\left(r_{p}\right)$ which is the probability that a randomly chosen-pair of progeny from the same array are full sibs.

For the four populations studied, MLTR was used to estimate the single-plant multilocus outcrossing rate jointly with gene frequencies $(p)$ of the outcrossing pollen pool.

To measure the effective selfing caused by consanguineous matings, $p$ estimates were regressed upon additive values of maternal genotypes [31, 33]. Additive values of $0,0.5$ and 1 were assigned to maternal genotypes aa, Aa and AA, respectively, where "A" is the most common allele and " $a$ " the class of other alleles at that locus.

\section{Results}

Pod set following open-pollination ranged from $45.7 \%$ in the Tunis population to $57.3 \%$ in the Amairia population with a mean of $53.3 \%$. Pod set following hand self-pollination varied from $24 \%$ in the El Alia population to $28.2 \%$ in the Amaïria population with a mean of $26.2 \%$. Mean seed numbers per pod over the four populations were 2.12 and 2.62 for hand self-pollination and open-pollination respectively. Mean number of aborted seeds per pod for hand self-pollination varied from 0.57 
in the Tunis population to 0.92 in the El Alia population. Lower seed abortion was observed after open-pollination, values ranged from 0.04 (in El Alia) to 0.15 (in Tunis). These results of pollination experiments indicate that Hedysarum coronarium is self-compatible and self-fertile.

Multilocus and average single-locus estimates of the outcrossing rate and their differences are given for each population in Table II. Gene frequencies for the ovule and pollen pools are presented in Table III. $\mathrm{t}_{\mathrm{m}}$ values ranged from 0.822 to 1.013 , suggesting a predominance of outcrossing in the set of populations studied. It was found that $t_{s}$ values were slightly lower than $t_{m}$ in two populations (El Alia and Tunis) hence positive $\left(t_{m}-t_{s}\right)$ differences.

The analysis of data under the ESM (Tab. IV) gave mean effective selfing rates (E) which ranged from 0.026 in Amaïria to 0.183 in El Alia. Considering inbred and outbred parents, strong divergence was found for the apparent selfing rate between them in the El Alia population $\left(\mathrm{S}_{\mathrm{i}}>\mathrm{S}_{\mathrm{o}}\right)$ (Tab. IV). Similarly, this population differed from the three others in terms of covariation of $\mathrm{E}$ with $\mathrm{F}$ : the populations of Amaïria, Tunis and Maktar did
Table II. Population estimates of the outcrossing rate for Hedysarum coronarium under the mixed mating model.

\begin{tabular}{lccr}
\hline Population & $\mathrm{t}_{\mathrm{m}}(\mathrm{SD})$ & $\mathrm{t}_{\mathrm{s}}(\mathrm{SD})$ & $\mathrm{t}_{\mathrm{m}}-\mathrm{t}_{\mathrm{s}}(\mathrm{SD})$ \\
\hline El Alia & $0.822(0.126)$ & $0.819(0.110)$ & $0.003(0.039)$ \\
Maktar & $0.925(0.090)$ & $0.937(0.099)$ & $-0.012(0.020)$ \\
Tunis & $0.833(0.066)$ & $0.828(0.064)$ & $0.005(0.020)$ \\
Amaïria & $1.013(0.055)$ & $1.030(0.051)$ & $-0.017(0.026)$ \\
\hline
\end{tabular}

$t_{m}$, multilocus outcrossing rate, $t_{s}$, single-locus outcrossing rate averaged over loci, and their difference. Variance estimates based upon 300 bootstraps (unit of resampling Family within population).

not show any covariation as a consequence of nearly zero F-values (Tab. IV). The positive covariation $(\mathrm{D}>0)$ observed in the El Alia population is known to maintain variation of $\mathrm{F}$ among population subdivisions [31, 32] and may reflect the occurrence of mating between relatives. Maternal parents appeared inbred in the El Alia population $(\mathrm{F}=0.159)($ Tab. IV).

There is great variation among estimates of single-plant outcrossing rates for the populations studied (Fig. 1). These estimates can be strongly

Table III. Allele frequencies for two variable loci in ovule and pollen pools for each population of Hedysarum coronarium.

\begin{tabular}{|c|c|c|c|c|c|c|c|c|c|}
\hline & & & Skdh-1 & & & & & & \\
\hline & 1 & 2 & 3 & 4 & 5 & 1 & 2 & 3 & 4 \\
\hline EL Alia & & & & & & & & & \\
\hline Ovule & - & 0.646 & - & 0.354 & - & - & 0.083 & 0.917 & - \\
\hline Pollen & - & 0.490 & - & 0.510 & - & - & 0.061 & 0.939 & - \\
\hline Maktar & & & & & & & & & \\
\hline Ovule & 0.018 & 0.411 & - & 0.571 & - & 0.024 & 0.246 & 0.702 & 0.018 \\
\hline Pollen & 0.07 & 0.493 & - & 0.437 & - & 0.035 & 0.170 & 0.786 & 0.019 \\
\hline Tunis & & & & & & & & & \\
\hline Ovule & - & 0.490 & 0.020 & 0.449 & 0.041 & - & 0.250 & 0.688 & 0.063 \\
\hline Pollen & - & 0.343 & 0.013 & 0.590 & 0.055 & - & 0.189 & 0.618 & 0.193 \\
\hline Amaïria & & & & & & & & & \\
\hline Ovule & 0.019 & 0.692 & - & 0.269 & 0.019 & - & 0.137 & 0.843 & 0.020 \\
\hline Pollen & 0.015 & 0.676 & - & 0.304 & 0.005 & - & 0.168 & 0.807 & 0.025 \\
\hline
\end{tabular}


(a)

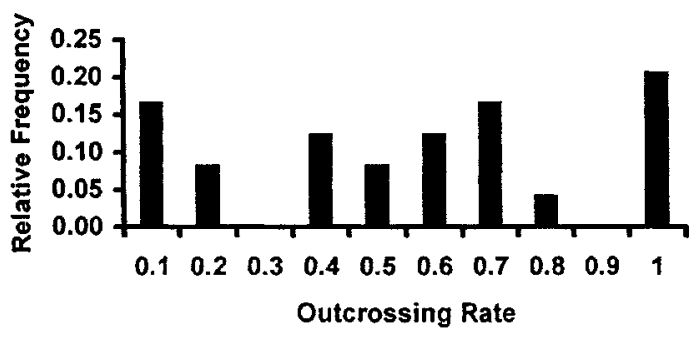

(b)

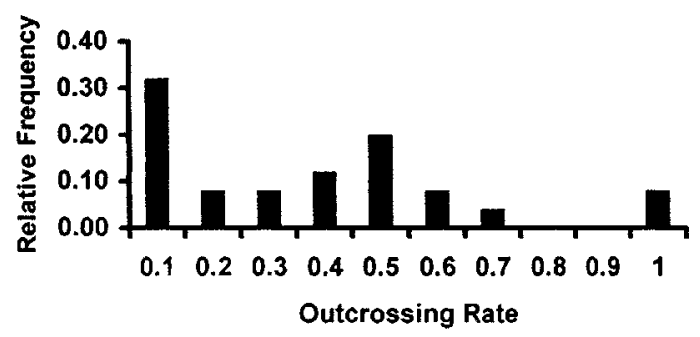

(c)

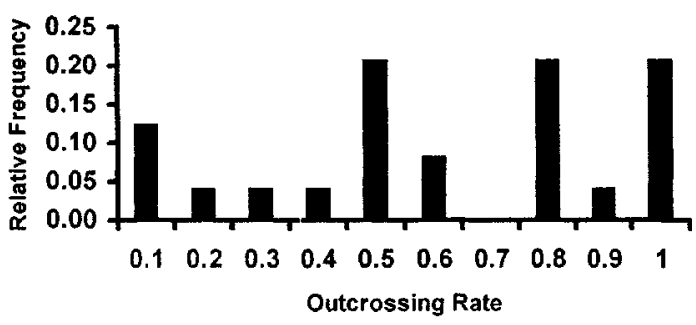

(d)

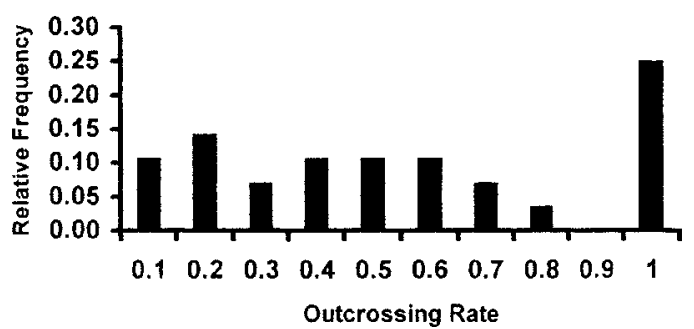

Figure 1. Distribution of outcrossing rates in El Alia (a), Amaïria (b), Tunis (c), and Maktar (d) populations of Hedysarum coronarium. affected by the influence of maternal genotype and population marker diversity on the probability of detecting outcrosses [43].

Although higher in Amaïria, El Alia and Maktar, $r_{t}$ was close to zero $\left(r_{t}=0.053\right)$ in Tunis $($ Tab. V), indicating more homogeneity of the outcrossing rate among maternal parents in this population.

Correlation of outcrossed paternity was very low $\left(r_{p}=0.029\right)$ in Tunis (Tab. V) suggesting frequent and successful multiple matings in this population. Although $r_{p}$ varied among populations, a value of 1 was never reached, therefore excluding the monopaternal origin of outcrossed progeny. The average mating pool (neighbourhood size) is calculated as the inverse of $r_{p}$ and is the number of males that gives rise to this correlation, assuming all males have equal mating probabilities and consecutive matings are independent [28]. This neighbourhood size varied between 2-3 plants in El Alia and 34-35 plants in Tunis (Tab. V).

The regression of outcrossing-pollen allele frequency on additive maternal genotype value varied widely among loci and populations (Tab. VI). Significant regression was observed only in the El Alia population at the Pgi-2 locus. A negative value of the coefficient is unlikely to be related to consanguineous matings.

\section{Discussion}

Variation in outcrossing rates between populations appears to be a common phenomenon in mixed mating species $[5,10,37]$. Our study of the mating system in $H$. coronarium indicates that outcrossing varies both within and between populations. The multilocus estimate is less affected by selection and non-random outcrossing than are single- locus estimates [5]. Differences between multilocus and mean single-locus outcrossing rates for individual populations provide a measure of biparental inbreeding [29, 33]. These differences were negligible for all the populations studied, thus it seems that biparental inbreeding is negligible. Localized seed dispersal, coupled with local pollen transfer, can lead to the development of population 
Table IV. Estimates of Hedysarum coronarium mating system parameters under the ESM.

\begin{tabular}{lcccc}
\hline & & & & \\
Parameters & Plia & Population & Tuktar \\
Estimate $(\mathrm{SD})$ & $95 \% \mathrm{CI}$ & $\begin{array}{c}\text { Tunis } \\
\text { Estimate }(\mathrm{SD})\end{array}$ & $\begin{array}{c}\text { Estimate }(\mathrm{SD}) \\
95 \% \mathrm{CI}\end{array}$ & $\begin{array}{c}\text { Estimate }(\mathrm{SD}) \\
95 \% \text { CI }\end{array}$ \\
\hline $\mathrm{E}$ & $0.183(0.087)$ & $0.110(0.084)$ & $0.140(0.064)$ & $0.026(0.23)$ \\
& $(0.018 ; 0.382)$ & $(0.001 ; 0.227)$ & $(0.004 ; 0.254)$ & $(0.001 ; 0.082)$ \\
$\mathrm{S}_{\mathrm{i}}$ & $0.716(0.298)$ & $0.001(0.417)$ & $0.094(0.427)$ & $0.010(0.473)$ \\
$\mathrm{S}_{\mathrm{o}}$ & $(0.001 ; 0.999)$ & $(0.001 ; 0.999)$ & $(0.001 ; 0.999)$ & $(0.001 ; 0.999)$ \\
& $0.082(0.101)$ & $0.110(0.089)$ & $0.140(0.067)$ & $0.026(0.008)$ \\
$\mathrm{F}$ & $(0.001 ; 0.362)$ & $(0.001 ; 0.297)$ & $(0.001 ; 0.252)$ & $(0.001 ; 0.026)$ \\
& $0.159(0.124)$ & $0.001(0.046)$ & $0.001(0.040)$ & $0.007(0.066)$ \\
$\mathrm{D}$ & $(0.001 ; 0.444)$ & $(0.001 ; 0.157)$ & $(0.001 ; 0.125)$ & $(0.001 ; 0.242)$ \\
& $0.085(0.048)$ & $0.000(0.015)$ & $0.000(0.018)$ & $0.000(0.019)$ \\
& $(0.000 ; 0.150)$ & $(-0.023 ; 0.052)$ & $(-0.009 ; 0.062)$ & $(0.000 ; 0.072)$ \\
\hline
\end{tabular}

E, average effective selfing rate; $S_{i}$ and $S_{0}$, effective selfing rates of inbred and outbred parents;

$F$, parental inbreeding coefficient; $D$, covariation of parental $F$ with $E$ : $D=F(1-F)\left(S_{i}-S_{o}\right)$.

Standard deviations (in parentheses) and 95\% confidence intervals based upon 1000 bootstraps.

subdivision and biparental inbreeding [19]. Nevertheless, $t_{m}$ was not strictly equal to unity except for population Amaïria.

The value of parental inbreeding was zero in three of the four populations (Maktar, Tunis and Amaïria). This suggests that parental inbreeding depression may occur before the adult stage [37]. This may be due to the presence of selection against biparentally inbred progeny, which can occur if genetic load is high [37]. Several lines of evidence indicate that selection operates against inbred progeny in self-compatible species [20]. This view is supported by high levels of seed abortion in hand self-pollination when compared to open-pollination. Thus, higher levels of embryo abortion may be responsible for maintaining elevated levels of outcrossing rates in populations [21]. The protandrous nature of flower development in $H$. coronarium, sequential flowering on the same inflorescence during anthesis period and competitive inferiority of self pollen reported for this species [8] are additional causes of a high outcrossing rate.

Analysis of the mating system under ESM indicates the occurrence of biparental inbreeding in the El Alia population since (i) the covariation of $\mathrm{E}$
Table V. Correlated mating parameters of Hedysarum coronarium under the sibling-pair model.

\begin{tabular}{lccc}
\hline Population & $r_{t}(\mathrm{SD})$ & $r_{p}(\mathrm{SD})$ & $\begin{array}{c}\text { Neighbourhood } \\
\text { size }\left(1 / \mathrm{r}_{\mathrm{p}}\right)\end{array}$ \\
\hline El Alia & $0.990(0.558)$ & $0.342(0.202)$ & $2-3$ \\
Maktar & $0.717(0.586)$ & $0.129(0.139)$ & $7-8$ \\
Tunis & $0.053(0.153)$ & $0.029(0.077)$ & $34-35$ \\
Amaïria & $0.990(0.891)$ & $0.184(0.204)$ & $5-6$ \\
\hline
\end{tabular}

$r_{t}$, correlation of outcrossing rate within progeny arrays;

$r_{p}$, correlation of outcrossed paternity within progeny arrays. Variance estimates based upon 300 bootstraps (unit of resampling $=$ family within population).

Table VI. Regression of the gene frequencies of the pollen outcrossing pool upon maternal genotypes for Hedysarum coronarium.

\begin{tabular}{lcccc}
\hline \multicolumn{5}{c}{ Population } \\
Locus & El Alia & Maktar & Tunis & Amaïria \\
\hline Skdh-1 & 0.03 & 0.102 & 0.055 & -0.102 \\
& $(\mathrm{NS})$ & $(\mathrm{NS})$ & $(\mathrm{NS})$ & (NS) \\
Pgi-2 & $-0.441^{* *}$ & -0.234 & -0.159 & -0.059 \\
& $(p=0.014)$ & $(\mathrm{NS})$ & $(\mathrm{NS})$ & $(\mathrm{NS})$ \\
\hline
\end{tabular}

Significance tested with ANOVA on the regression coefficient. 
with $\mathrm{F}$ is positive $(\mathrm{D}=0.085)$ and (ii) $\mathrm{S}_{\mathrm{i}}>\mathrm{S}_{\mathrm{o}}$ indicating that inbred parents effectively self more than outbred parents. Similar results were reported in subdivided populations [12, 25, 31]. A positive value of $F(F=0.159)$ in El Alia indicates that selfed progeny survived to maturity. This may be an example of the "heterozygosity paradox" of Brown, who found that homozygosity showed a puzzling excess in outbreeders [3]. In addition, covariance of selfing with gene fixation may have consequences on fitness in El Alia. In fact, for inbred or homozygous neighbourhoods where effective selfing rates are higher, deleterious recessives become less frequent and alleles advantageous in the homozygous condition may increase in frequency [32].

Variation of the mating system within populations is assessed by among-plant variation of the outcrossing rate. The distribution of family $\mathrm{t}_{\mathrm{m}}$ estimates (Fig. 1) is nearly bimodal in the El Alia population with more than $50 \%$ of plants virtually completely selfed or outcrossed which seems in accord with the high correlation of outcrossing $\left(r_{t}\right.$ $=0.990$ ). Within progeny arrays in the Amaïria and Maktar populations, classes of intermediate outcrossing are observed and high $r_{t}$ values may be attributed to the presence of important classes of highly selfing (Amaïria) or highly outcrossing (Maktar) plants. In the Tunis population, $\mathrm{t}_{\mathrm{m}}$ for maternal plants were more dispersed and hence may explain a low correlation of outcrossing within progeny arrays $\left(r_{t}=0.053\right)$. Variation in estimates of single-plant outcrossing rates may arise from variation in the distance to nearest neighbours [36] (as in the El Alia population), genetic differences in levels of self-fertility [6] and asynchrony in flowering times [13, 21, 24].

Correlation of outcrossed paternity within progeny arrays $\left(r_{p}\right)$ was recently estimated for the herbaceous annual Centaurea solstitialis [37] and for two woodland shrub Daviesia suaveolens and D. mimosoides [43]. In these three pollinatordependent outbreeders, $r_{p}$ estimated with MLTR ranged from 0.047 to 0.636 . In our study, $r_{p}$ varied from 0.029 in Tunis to 0.342 in El Alia. The last value indicates that $34 \%$ of outcrossed seeds share the same male parent and $66 \%$ do not. As the outcrossing rate is 0.82 in the El Alia population, 54\% of the total seeds in the progeny array share different paternal parents. The chance of producing outcrossed full-sibs is increased in a small sparse population like the El Alia. A similar result was reported for two populations of Daviesia mimosoides [43]. In the three other populations of $H$. coronarium, despite the differences observed in their outcrossing rates, the proportion of multipaternal seeds was approximately the same $(80 \%)$, reflecting a high diversity of pollen donors in these populations. A decrease in $r_{p}$ increases the neighbourhood size as in the Tunis population where the average "paternal mating pool" was 34-35 which is larger than the progeny array sample size. A similar result was obtained by Sun and Ritland [37] in one population of Centauria solstitialis.

H. coronarium is becoming an important forage species and breeding programs for its improvement should include determination of its mating system and quantitative estimation of its genetic parameters. The half-sib relationship among progeny within open-pollinated families often assumed [42] when estimating additive genetic variance and the heritability of traits, is not usually met as shown by our results. With a half-sib relationship, the genetic correlation among progeny is 0.25 , indicating that the progeny have $1 / 4$ of their genes in common. Any degree of correlated mating, mating among relatives, or self-fertilization will cause an increase in the coefficient of relationship [38].

The violation of the half-sib assumption will result in overestimations of additive genetic variance, heritability and, subsequently, genetic gains [16]. In an entomophilous species, like H. coronarium, the combination of pollinator behaviour and genetic substructuring may create a hierarchy of correlated matings within inflorescences and individual plants [5]. Thus, according to our study, $20 \%$ to $46 \%$ of the total seeds in the progeny array are full-sibs. Therefore, the coefficient of relationship is expected to be higher than 0.25 . 


\section{References}

[1] Baatout H., Comparison of phenotypic variation in self-fertilizing and outcrossing subspecies of Hedysarum spinosissimum, a Mediterranean herb, Plant Genet. Resour. Newslett. 105 (1996) 23-28.

[2] Baatout H., Marrakchi M., Mathieu C. , Vedel F., Variation of plastid and mitochondrial DNAs in the genus Hedysarum, Theor. Appl. Genet. 70 (1985) 577-584.

[3] Brown A.H.D., Enzyme polymorphism in plant populations, Theor. Pop. Biol. 15 (1979)1-42.

[4] Brown A.H.D., Allard R.W., Estimation of the mating system in open-pollinated maize populations using isozyme polymorphisms, Genetics 66 (1970) 133-145.

[5] Brown A.H.D., Burdon J.J., Jarosz A.M., Isozyme analysis of plant mating system, in: Soltis D.E., Soltis P.S. (Eds.), Isozymes in Plant Biology, Discorides press, Portland, USA, 1989, pp. 73-86.

[6] Charlesworth D., Yang Z., Allozyme diversity in Leaven worthia populations with different inbreeding levels, Heredity 81 (1998) 453-461.

[7] Chriki A., L'hérédité des anthocyanes florales chez Hedysarum coronarium L., H. carnosum Desf. et H. capitatum Desf. Ash et Gr, thèse de Doctorat d'État, Univ. Pau et des Pays de l'Adour, 229 p., 1986.

[8] Chriki A., Combes D., Marrakchi M., Étude de la compétition pollinique chez le Sulla (Hedysarum coronarium L.), Agronomie 4 (1984) 155-159.

[9] Clegg M., Measuring plant mating systems, Bioscience 30 (1980) 814-818.

[10] Coates D.J., Sokolowski R.E., The mating system and patterns of genetic variation in Banksia cuneata A.S. George (Proteaceae), Heredity 69 (1992) 11-20.

[11] Combes D., Espagnac H., Figier J., Étude de populations naturelles d'Hedysarum coronarium L. du Nord de la Tunisie, Bull. Soc. Hist. Nat. Afr. Nord 66 (1975)107-122.

[12] Coutellec-Vreto M.A., Madec L., Guiller A., Selfing and biparental inbreeding: a mating system analysis in Lymnaea peregra (Gastropoda: Lymnaeidae), Heredity 79 (1997) 277-285.

[13] Cruzan M.B., Hamrick J.L., Arnold M.L., Bennett B.D., Mating system variation in hybridizing irises: Effects of phenology and floral densities on family outcrossing rates, Heredity 72 (1994) 95-105.
[14] El Gazzeh M., Contribution à l'étude du système de reproduction sexuée de populations de Sulla (Hedysarum coronarium L.), conséquences sur la structure génétique, thèse d'État, Faculté des Sciences de Tunis, 261 p., 1992.

[15] Ellstrand N.C., Marshall D.L., Interpopulation gene flow in wild radish, Raphanus sativus, Am. Nat. 126 (1985) 606-616.

[16] Falconer D.S., Introduction to Quantitative Genetics, 3rd ed., Longman scientific and technical, New York, 1989.

[17] Figier J., Étude de la variabilité et du déterminisme de la morphologie de Hedysarum coronarium L. en Tunisie. Implications concernant l'amélioration de cette espèce fourragère dans ce pays, thèse de Doctorat d'État, Université Paris-Sud, 1982.

[18] Fyfe J.L., Bailey N.T.J., Plant breeding studies in leguminous forage crops. I. Natural crossbreeding in winter beans, J. Agric. Sci. 41 (1951) 371-378.

[19] Godt M.J.W., Hamrick J.L., The mating system of Liatris helleri (Asteraceae); a threatened plant species, Heredity 75 (1995) 398-404.

[20] Hamrick J.L., Isozymes and the analysis of Genetic structure in Plant Populations, in: Soltis D.E. (Ed.), Isozymes in Plant Biology, Discorides press, Portland, USA, 1989, pp. 87-105.

[21] Kennington W.J., James S.H., The effect of small population size on the mating system of a rare clonal mallee, Eucalyptus argutifolia (Myrtaceae), Heredity 78 (1997) 252-260.

[22] Morgan M.T., Barrett S.C.H., Outcrossing rates and correlated mating within a population of Eichhornia paniculata (Pontederiaceae), Heredity 64 (1990) 271-280.

[23] Muona O., Moran G., Bell J.C., Hierarchical patterns of correlated mating in Acacia melanoscylon, Genetics 127 (1991) 619-626.

[24] Petit C., Lesbros P., Ge X., Thompson J.D., Variation in flowering phenology and selfing rate across a contact zone between diploid and tetraploid Arrhenatherum elatius (Poaceae), Heredity 79 (1997) 31-40.

[25] Ritland K., The effective proportion of self-fertilization with consanguineous matings in inbred populations, Genetics 106 (1984) 139-152.

[26] Ritland K., Joint maximum likelihood estimation of genetic and mating structure using open-pollinated progenies, Biometrics 42 (1986) 25-43. 
[27] Ritland K., The genetic-mating structure of subdivided populations. II. Correlated mating models, Theor. Pop. Biol. 34 (1988) 320-346.

[28] Ritland K., Correlated matings in the partial selfer Mimulus guttatus, Evolution 43 (1989) 848-859.

[29] Ritland K., A series of FORTRAN computer programs for estimating plant mating systems, J. Hered. 81 (1990) 235-237.

[30] Ritland K., MLTR Multilocus mating system program Version 1.1 (1996), available from author.

[31] Ritland K., Ganders F.R., Variation in the mating system of Bidens menziesii (Asteraceae) in relation to population substructure, Heredity 55 (1985) 235-244.

[32] Ritland K., Ganders F.R., Covariation of selfing rates with parental gene fixation indices within populations of Mimulus guttatus, Evolution 41 (1987) 760-771.

[33] Ritland K., Jain S.K., A model for the estimation of outcrossing rate and gene frequencies using $\mathrm{n}$ independent loci, Heredity 47 (1981) 35-52.

[34] Ritland K., El-Kassaby Y.A., The nature of inbreeding in a seed orchard of Douglas-fir as shown by an efficient multilocus model, Theor. Appl. Genet. 71 (1985) 375-384.

[35] Schoen D.J., Mating system estimation via the one pollen parent model with the progeny array as the unit of observation, Heredity 60 (1988) 439-444.

[36] Smyth C.A., Hamrick J.L., Variation in estimates of outcrossing in musk thistle populations, J. Hered. 75 (1984) 303-307.
[37] Sun M., Ritland K., Mating system of yellow starthistle (Centaurea soltistialis), a successful colonizer in North America, Heredity 80 (1998) 225-232.

[38] Surles S.E., Arnold J., Schnabel A., Hamrick J.L., Bongarten B.C., Genetic relatedness in open-pollinated families of two leguminous tree species, Robinia pseudoacacia L. and Gleditsia triacanthos L., Theor. Appl. Genet. 80 (1990) 49-56.

[39] Trifi-Farah N., Chatti W.S., Marrakchi M., Pernès J., Déterminisme génétique de dix systèmes enzymatiques chez Hedysarum coronarium L., Agronomie 9 (1989) 503-510.

[40] Trifi-Farah N., Chatti W.S., Marrakchi M., Pernès J., Analyse de la variabilité morphologique et enzymatique des formes cultivées et spontanées de Hedysarum coronarium L. en Tunisie, Agronomie 9 (1989) 591-598.

[41] Wendel J.F., Weeden N.F., Visualization and interpretation of plant isozymes, in: Soltis D.E., Soltis P.S. (Eds.), Isozymes in plant Biology, Discorides press, Portland, USA, 1989, pp. 5-45.

[42] Yang R.-C., Yeh F.C., Yanchuk A.D., A comparison of isozyme and quantitative genetic variation in pinus contorta ssp. latifolia by $\mathrm{F}_{\mathrm{ST}}$, Genetics 142 (1996) 1045-1052.

[43] Young A.G., Brown A.H.D., Comparative analysis of the mating system of the rare woodland shrub Daviesia suaveolens and its common congener $D$. mimosoides, Heredity 80 (1998) 374-381. 